Marquette University

e-Publications@Marquette

Clinical Lab Sciences Faculty Research and

Publications

Clinical Lab Sciences, Department of

$9-2020$

Biographical Feature: Robin Patel, M.D.(C.M.), D(ABMM), F(AAM), FIDSA, FACP

Erik Munson

Follow this and additional works at: https://epublications.marquette.edu/clinical_lab_fac

Part of the Laboratory and Basic Science Research Commons 


\title{
Biographical Feature: Robin Patel, M.D.(C.M.), D(ABMM), F(AAM), FIDSA, FACP
}

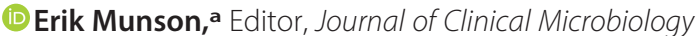

aCollege of Health Sciences, Marquette University, Milwaukee, Wisconsin, USA

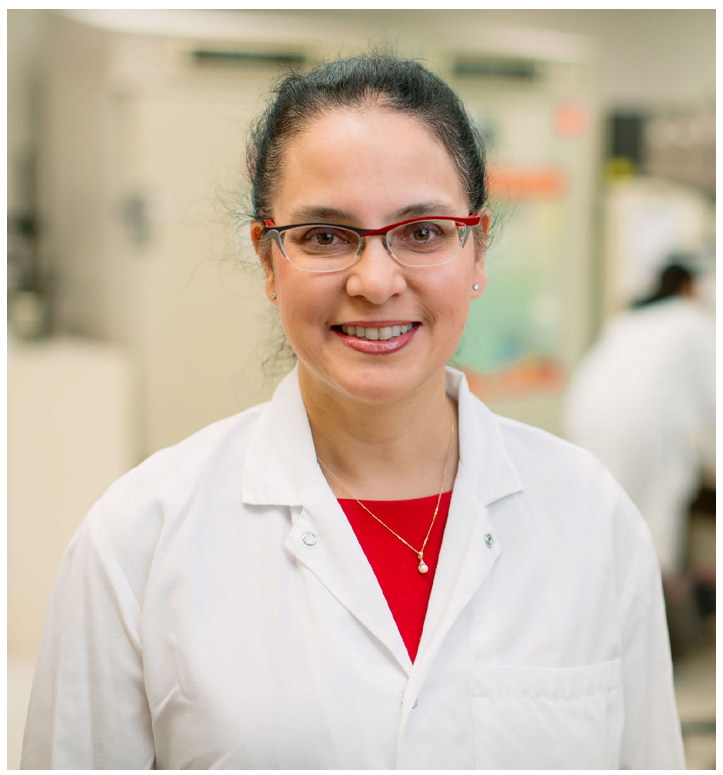

"I just always loved science. As far back as I can remember, I knew I would be a medical doctor working in science. I immersed myself in science in elementary and high school, participating, for example, in science fairs, which, in Canada, are structured a little differently than in 'the States.' I did a lot of work on my own; my projects were quite homemade, performed, for the most part, in my basement. There was no formal collaboration with any particular outside vendor, though my parents were supportive, even if I made a big mess of their house; one of the highlights was that I got to go to the Canada-Wide Science Fair, which, for a student working out of their basement, was exciting. I got to travel and met other students with a similar passion, learning what they did and what inspired them."

Derhaps it is not surprising that an already legendary career of clinical excellence, unparalleled medical microbiology research contributions, and service to the microbiology and infectious diseases communities may very well have germinated from this grade school basement mad scientist. Robin Patel, M.D., the Elizabeth P. and Robert E. Allen professor of individualized medicine, professor of microbiology, and professor of medicine at the Mayo Clinic in Rochester, Minnesota, is the subject of this biographical feature. She is recognized and lauded as a pioneer, mentor, and leader in the field

Citation Munson E. 2020. Biographical Feature: Robin Patel, M.D.(C.M.), D(ABMM), F(AAM), FIDSA, FACP. J Clin Microbiol 58:e01259-20. https://doi.org/10.1128/JCM.01259-20. Editor Alexander J. McAdam, Boston Children's Hospital

Copyright $\odot 2020$ American Society for Microbiology. All Rights Reserved.

Address correspondence to erik.munson@marquette.edu.

Accepted manuscript posted online 24 June 2020

Published 24 August 2020 
of clinical microbiology. Peter H. Gilligan, Ph.D. (1), currently adjunct professor of pathology-laboratory medicine at the University of North Carolina School of Medicine, succinctly summarized Patel's status in the field of clinical and medical microbiology, "Dr. Patel is probably the single most accomplished person that I know in the field of clinical microbiology." Richard B. (Tom) Thomson, Jr., Ph.D. (2), medical microbiologist from NorthShore University Healthcare in Evanston, Illinois, added, "There are natural leaders in our profession from and with whom we all seek out to learn and collaborate. Robin is one of these. She is a preeminent scientist that I follow and seek collaboration with to improve my understanding of clinical microbiology." In a recent interview with Patel, the phrase "make a difference" was uttered with high frequency; what follows is an attempt to chronicle how Robin Patel has made a difference in clinical microbiology and its affiliated disciplines.

Robin Patel was born in Winnipeg, Manitoba, Canada. She and her family moved to the suburbs of Montreal, Québec, when she was four years old, and she is a product of the public-school system. She was educated in "French immersion" in an Englishspeaking school during most of her schooling. Patel noted that secondary education in Québec is different than that in the United States, in that high school runs from the seventh grade through the eleventh grade. In many circumstances, individuals who plan to attend a university matriculate in a two-year Collège d'enseignement general et professionnel (CEGEP) program (3) following high school. Patel's completion of a year in a CEGEP program at Marianapolis College in Montreal facilitated her completion of baccalaureate studies (with magna cum laude honors) at Princeton University in three years. She remarked, "I didn't come from a wealthy background, and Princeton was a little pricey, so I thought it was a good idea to hurry up my education; I'm not sure I would have made that decision today." Patel majored in chemistry and described how Princeton mandated a junior year project as well as an undergraduate senior thesis. Patel used laboratory (chemistry) research to fulfill these requirements. She chuckled, "I loved working in the laboratory, doing independent work; I had a lot of fun with that. I am certain that I did not make a major contribution to science at that time, but I did learn a lot. Princeton provided unique opportunities that would shape my research career."

Patel returned to Canada for medical school, entering McGill University in Montreal on a full scholarship. Her intention was to complete postgraduate training in the United States and then return to Canada to practice. Those plans obviously changed upon her ultimate decision of training location. She recollected, "I interviewed at a number of places on the East Coast and in the Midwest. I didn't have a lot of resources, so I applied to places within driving distance. [Mayo Clinic] was a different interview than those I had experienced at any of the other places that I looked at, and that was what made up my mind; there was a distinct focus." Mayo Clinic has been characterized by some $(2,4)$ as being rather unique for its patient-centered philosophy, even with respect to diagnostic and basic science paradigms. One past doctoral student of Patel (whose professional affiliation restricted them from going on record but hereby is gratefully acknowledged for their contribution to this biographical feature) related that the unique opportunity of rounding with Patel (on transplant infectious diseases) was experienced on multiple occasions. One thing that was learned from observing Patel in this role was the belief that (hospitalized) patients were most often the best source of information for what was going on with their cases; Patel essentially instilled the fact that directly asking at the source is generally the most efficient approach.

Patel decided upon internal medicine residency training at Mayo Clinic because it allowed the opportunity to "dive deep" into other areas of medicine (one of which was infectious diseases, for which she completed fellowship training at Mayo Clinic in 1995). Again, because her original intention was to return to Canada, and because in Canada (Québec, in particular) many infectious diseases practitioners are also clinical microbiologists (similar to the British system), she decided to additionally complete a clinical microbiology fellowship (by way of an American Board of Pathology training program) at Mayo Clinic in 1996. In the end, Patel learned that she "absolutely loved clinical 
microbiology. Clinical microbiology seemed like the perfect area where I could work in science and medical practice, making a difference with laboratory science and bringing research to the table as well. That experience would forever change my career."

Patel was already engaged in nondedicated research time during residency training and published nearly two dozen manuscripts prior to her first academic appointment at Mayo Clinic in 1996. Her research career began to explode during her infectious diseases fellowship under the tutelage of Carlos Paya, M.D. Dr. Paya was a virologist by trade, and Patel "cut her teeth" on cytomegalovirus $(5,6)$. Patel recalled, "It was the early 1990s when the field of transplant infectious diseases was being birthed. Mayo Clinic was one of the first places to have a formal clinical transplant infectious diseases program; the opportunity to study infectious diseases in this patient population was unprecedented. Much of what we know to be true today was in the process of being learned back then. [Dr. Paya] was a natural person for me to work with and to train me in laboratory-based but, at the same time, translational research; this molded my career." This notes one early example of a paradigm that has been consistent throughout Patel's career: applying skills as a basic scientist to clinical needs in the field.

With Mayo Clinic being one of the early leaders in transplant infectious diseases, it also was one of the first clinical locations to recognize the importance of vancomycinresistant Enterococcus spp. (VRE) in transplant populations (7). Patel recollected, "We were able to track the first introduction and spread of VRE into our health care institution, in addition to understanding VRE therapeutics, all because of our transplant program, which is where I had cut my teeth in translational research." As a result, she was instrumental in developing assays to detect vancomycin resistance in these organisms, described a new vancomycin resistance gene in enterococci (8), and defined a homolog to vancomycin resistance genes in enterococci in the biopesticide Paenibacillus popilliae (9). Patel concluded, "For me, it started off as just another type of infection affecting the patients I was seeing (the transplant patients) and then became a really interesting scientific area."

Upon full-time faculty appointment, Patel assumed directorship of the infectious diseases research laboratory at Mayo Clinic, largely on account of a desire of her collaborator, Dr. James Steckelberg, to return to clinical practice. She continued a strong collaboration with Dr. Steckelberg relative to his long-standing interests in bone and joint infections (10) and endocarditis (11). Bone and joint infection research was of heightened interest because Mayo Clinic had introduced an orthopedic infectious diseases clinical service to complement a large orthopedic surgery referral service. As time progressed, the frequency of arthroplasty procedures increased, and the entity of periprosthetic joint infection had become commonplace. In the words of Patel, colleagues approached her claiming that this was "essentially a new disease, but we are using the same diagnostics that we had been using for native joint infection. We have gaps in this field, and we think that someone like you, who is trained in clinical microbiology and translational research, could help come up with better ways of diagnosing and treating periprosthetic and other orthopedic implant-associated infections."

At the same juncture, Patel's research laboratory was busy characterizing medical biofilms, relative to organisms including Staphylococcus lugdunensis (12), Candida albicans, and Pseudomonas aeruginosa. Patel then reasoned (with growing exuberance in her voice), "Wow, if we take the understanding of biofilms that is coming from environmental microbiology-more so than medical microbiology-and put that together with what is happening with orthopedic implant-associated infections, I think we stand a chance of being better to understand what is going on and probably to come up with better diagnostics and therapeutics. So, I listened to my colleagues, and I reasoned, 'I think this is a field that needs improvement; I am going to try to make a difference."' The convergence of these events resulted in, according to Shawn Vasoo, MBBS, MRCP (clinical director, head of infectious diseases research laboratory, National Centre for Infectious Diseases, Singapore), "seminal work on biofilm-associated infections, particularly sonication of prosthetic orthopedic devices for infections (13) and in 
further defining how these should be applied clinically." Elitza S. Theel, Ph.D., director, infectious diseases serology laboratory at Mayo Clinic, concurred, "Dr. Patel's most influential work has really revolved around improving diagnostics for prosthetic joint infections. This includes both her innovative work around sonication of explanted prosthetic joints to increase the recovery of bacteria and, more recently, the application of metagenomics for identification of the more difficult-to-detect pathogens."

Patel also chairs the Division of Clinical Microbiology in the Department of Laboratory Medicine and Pathology at Mayo Clinic. Thomas F. Smith, Ph.D. (4), emeritus chair of the Division of Clinical Microbiology at Mayo Clinic, wrote, "Dr. Patel is an iconic physician who, as chair of the Division of Clinical Microbiology, leads a very talented group of microbiologists. She encourages their development by her independent skills of outstanding writing and appreciation of collaboration with clinical colleagues (she also appreciates the connective and translative role of a clinical microbiologist with the practice of medicine) and focus on an extremely strong work ethic." Alexander J. McAdam, M.D., Ph.D., current editor in chief of Journal of Clinical Microbiology, wrote that Patel is able to recognize and implement promising new methods very quickly. "She was among the first in the United States to see the potential of matrix-assisted laser desorption ionization-time of flight mass spectrometry for microbiology (14) and was a leader for introducing this method into clinical use."

Not to be lost in the realm of clinical microbiology and translational research is the potential contribution of the bench technologist. Patel opined, "Bench technologists can become better bench technologists by desiring to become better bench technologists, by being interested in what they are doing, and by asking probing questions. Questioning and having an open eye can make a difference." She noted that important findings and changes in laboratories can emanate not only from the laboratory director but also from a bench technologist. Patel then related a story of how one esoteric plate finding from a bench technologist translated into a multicenter investigation that linked high serum levels of ammonia in lung transplant recipients with Ureaplasma infection, rendering an often-fatal disease curable (15). She additionally offered her opinion that clinical microbiology is in the midst of a massive technology revolution. As a result, some testing may leave the physical microbiology laboratory for other clinical settings, such as at the point of care. With that, she warned, "There remains a need for our medical science expertise; we should lead the science" and followed up by remarking that "we're able to do so many things today that we could never do 10 or 15 years ago. Our practice will continue to change; it is just so exciting to think about how we're going to increasingly make a difference in patient care."

Commitment to clinical and translational research is further exemplified by more than 450 peer-reviewed publications, a larger number of abstracts, and nearly two dozen book chapters. She is also listed on two United States patents related to her work on biofilms as well as a direct detection method for Bordetella spp. Patel's laboratory currently has stewardship or costewardship over 9 federal grants or subawards, 12 industry grants, and 4 institutional awards. She has been bestowed with numerous honors, including fellowship in the American Academy of Microbiology in 2012, the BD Award for Research in Clinical Microbiology in 2015, and the Mayo Medical School Distinguished Service Award.

Patel has fulfilled a second major component of the academic triad, namely, teaching, in robust fashion. When asked to comment about Patel, Dr. Gilligan cited her directorship of the medical microbiology course at the Mayo Clinic Alix School of Medicine. "She gets people excited about clinical microbiology. I, myself, have learned much about teaching from her." Patel first taught in the course as a fellow and has directed this course since 2001. She shared, "I love to teach. In medical science, there is a culture of education. We always have trainees, and we are always teaching the next generation; at the same time, I learn so much from the students. I particularly enjoy working with students who are learning something for the first time or in a new way and will take that knowledge and apply it in the world and probably advance it at the same time." Advancements in technology have altered the means of medical student 
education over the years; Patel largely sees herself nowadays in the role of a facilitator or tour guide. "Different learners prefer to learn in different ways, and that comes back to the tour guide analogy; we just need to make sure everybody on the tour is staying with the program and learning what they're supposed to be learning. It is fine if each learner gets there in slightly different ways."

Patel's commitment to teaching extends into mentorship. Her provided curriculum vitae lists 14 pages' worth of students who have worked or completed projects in her research laboratory. Her curriculum vitae itemizes papers (which number in the dozens) in which the primary author was a Patel mentee. She summarized her research mentorship philosophy as such: "In my research laboratory, there's a culture of having people from all over the world train as part of our laboratory team. We have had laboratory members-I call them laboratory family members-from Asia, Australia, Latin America, Europe, Canada (anywhere, really). I have Ph.D. students, medical students, postdocs, and so forth; for me, it's a natural way of doing research-we do research, we train people to do research, and we all learn together, leveraging my experience from the past, to move in a good direction together. A key component of my research team is the three research technologists, Kerryl Greenwood-Quaintance, Melissa Karau, and Suzannah Schmidt-Malan, who have been part of my team for 25, 15 , and 10 years, respectively."

The previously mentioned doctoral trainee of Patel related the experience of how, for a Ph.D. student (rather than a medical student or fellow), an extended-duration and more substantive research project would have to be devised. Patel conceived a new, appropriately sized project seemingly overnight. Bobbi S. Pritt, M.D., director, clinical parasitology laboratory at Mayo Clinic, and an editor for the Journal of Clinical Microbiology, was also a clinical microbiology fellowship trainee at Mayo. She wrote, "Right from the start, Dr. Patel challenged me to think independently and use the results of my own literature review and analysis of the data to answer clinical questions." Patel's accommodating style is conducive to these relationships. Dr. Vasoo commented, "Despite being very busy, I was personally very touched by how she always made time for her fellows. We would meet weekly, one on one, and it would be dedicated time for us to discuss issues with research or with training, to ask questions, and to catch up. That's been something which has profoundly influenced me and how I relate to and mentor trainees." Dr. Theel added that during her one-on-one fellowship interview with Patel, "I remember being amazed at how focused she was on me and on what I was saying, despite her pager buzzing, her phone ringing, and her email inbox filling. I realized then that she is the type of individual who, once dedicated to something, does not get easily distracted and sees it through to completion."

Patel segued into a third pillar of the academic triad (service) by opining, "When you're at your institution running your laboratory and things are going well, you look for other ways to contribute to the field (and learn at the same time), such as serving the government, societies, and other groups." She is director of the National Institutes of Health $(\mathrm{NIH})$ Laboratory Center for the NIH's Antibacterial Resistance Leadership Group (16) and an advisor to the Clinical and Laboratory Standards Institute Subcommittee on Antimicrobial Susceptibility Testing (17). She is also a past chair of the U.S. Medical Licensing Examination Microbiology and Immunology Test Material Development Committee. Patel served as an associate editor for Journal of Clinical Microbiology from 2009 to 2019, currently serves as an associate editor for Clinical Infectious Diseases, has served as an editorial board member for Clinical Microbiology Reviews and Antimicrobial Agents and Chemotherapy, and is a volume editor for the 12th edition of Manual of Clinical Microbiology.

With all of that said, perhaps Patel's most renowned contributions to professional societies (particularly the American Society for Microbiology [ASM]) have been in the form of leadership. Dr. Thomson wrote, "Robin has been instrumental in establishing the sound scientific focus of clinical microbiology ... as a chair of many professional committees, she easily solicits broad participation, ensures accomplishment of all tasks, and is appreciative of everyone's efforts." One of Patel's first major ASM leadership 
contributions involved her two stints on the Interscience Conference on Antimicrobial Agents and Chemotherapy (ICAAC) Program Committee (from 2002 to 2007 and from 2012 to 2015). She recalled, "I had a fantastic time programming their meeting and loved meeting the other members of the program committee and hearing about what they saw as important new areas in the field of infectious diseases and microbiology. Learning how to program a meeting, how to handle abstract review, and generally how to put together a meeting on behalf of a society was so rewarding. This was a fantastic way to volunteer my time. I was able to give back to something that was previously given to me." Dr. Gilligan remarked that of all of the activities in which he has participated with ASM, "I got the most pleasure working with ICAAC because of working with Robin Patel. We were teammates; she wasn't the boss."

When the decision was made to merge the ICAAC and the ASM General Meeting, Patel and several microbiologists formed the ASM Microbe 2016 Steering Committee. Following service on the ASM board of directors from 2017 to 2018, Patel was asked to run for the office of ASM president. She is completing her one-year term at the time of this writing and described the role that a president serves within this scientific society: "The president attempts to represent the over 30,000 members of the American Society for Microbiology - this is impossible to do without a glitch, obviously; it has been a big learning experience for me! You're not representing yourself, you're representing the society and its members and yet trying to speak with one 'ASM' voice to the public, to other scientific societies, and also, of course, to the membership of ASM. ASM is such a large society and is so diverse that representing everyone and everything ASM does and represents is challenging. There are so many different types of microbiologists involved; but this is also ASM's strength."

Patel remarked that becoming ASM president made her realize and understand how much work the society does, some of which may be unbeknownst to many. She cited one program as an example. Milestones in Microbiology recognizes locations or specific sites that have made historic contributions to the field of microbiology (https://lib .guides.umbc.edu/c.php?g=836720\&p=6543681\#s-lg-box-wrapper-26527244). As ASM president, Patel dedicated two new sites during her term, one of which was the Saranac Laboratory (subsequently assimilated into the Trudeau Institute in 1964) in upstate New York for their work on Mycobacterium tuberculosis. Again, with great zeal, she commented, "For ASM to recognize these sites is so important; if microbiologists don't recognize microbiologists and microbiology, no one else will. At Saranac Lake in particular, this dedication wasn't just for the microbiologists but for the general public that lived there, many of whom didn't appreciate the importance of the science that had happened there; this was the first facility in the United States built specifically for research on tuberculosis. While they did understand the importance of the sanatorium and the tuberculosis patients and their treatment, the dedication highlighted its importance to the field of microbiology. For example, decades of research conducted there led to the finding that both $M$. tuberculosis and the environment contribute to the development of tuberculosis. This site is of enormous importance for microbiology; it was my pleasure to be able to help recognize it." Patel also traveled to several ASM branch meetings during her presidency. With further enthusiasm, she commented, "Wow, I was just so impressed with what goes on locally. There is so much depth and richness at the branch level, with many branches having a particularly large contingent of students. I've learned that ASM touches so many at so many levels. I have been impressed with the way a society can bring people together and elevate microbiology for the scientists and the communities in which we live."

One of Patel's current research interests is worldwide antimicrobial resistance in general and, specifically, the role of laboratory diagnostics in mitigating spread of resistance (18). She reasoned, "Part of the problem is that we just haven't had good diagnostics. This has bred a culture of empiricism in terms of antibiotic usage, with many infectious diseases being treated based on a laying of the hands on a patient, with a history and physical, a pronouncement of a clinical diagnosis, and a prescription for an antibiotic. Today, we can do this much more precisely, better using our precious 
antibiotics and better caring for our fellow humans; I think this is just going to continue to improve." Patel has used her platform as ASM president within the past year to broadcast a similar message. She participated in global events hosted around the United Nations General Assembly and the World Health Organization as an ASM representative.

An obvious recent paradigm in which Patel's leadership has been sought as ASM president is the SARS-CoV-2 infection pandemic. When assuming the office of president, Patel intimated that she recognized that "there's always a possibility that a global health crisis happens during the year one is president." Patel used her office as an opportunity to educate media, to speak to the United States government in a nonpartisan fashion, and to advocate for microbiologists on behalf of the society (augmenting the long-standing role of ASM in this regard).

Stefano Bertuzzi, Ph.D., chief executive officer of ASM, commented about the complementary role of a president within a scientific society: "Essentially, the role of the CEO is that of running the society, and that of president as chair of the board is to ensure that the organization is run well and provide constructive input when course correction is needed. I think that Dr. Patel has understood and embodied these concepts perfectly." To that end, "Robin is also a visionary person. She understands the field of clinical microbiology of today. She has a vision for what clinical microbiology needs to be tomorrow, and this is invaluable as ASM president; she does not tinker with minutiae. She is a big-picture person with a vision." Dr. Bertuzzi further commented that ASM was fortunate to have a world subject matter expert as its president during the SARS-CoV-2 infection pandemic (19). "Never before has the mission of ASM come more into focus ... I could not be more thankful to Dr. Patel and her colleagues for the service not only to ASM but to the global community at a perilous moment."

The obvious question that arises in the minds of many is, how does all of this get accomplished? The expression "woman with superpowers" was mentioned by approximately one-third of interviewees. One noted immaculate time management skills, resulting in the completion of more work in one day than what most people can complete in one week (or two). Dr. Gilligan hypothesized that if one were to do a Google image search for "multitasker," Robin Patel's likeness would show up. Patel's humble and matter-of-fact retort to the same question was, "I almost always work in teams, rarely doing anything alone. It's by working together that we get things done." She also thanked her husband, Norbert, and their two children, David and Michelle, for their unwavering support of her career. Colleague-described attributes such as "approachable and inclusive," "cheerful and optimistic," "terribly smart/brilliant," "very observant," "photographic memory," "energetic," "keen sense of humor," "laughs a lot," "an eye for detail," "great communicator," and "self-effacing—she doesn't have to be the smartest person in the room" likely also contribute to Patel's overall success in and impact on the field.

To conclude, besides the general realm of science motivating Dr. Robin Patel along her career path, one also returns to the patient-centered experience as a motivating factor. She explained, "When you know that what you are doing could potentially make someone's life better or save a life, that's highly motivating. We can see it-small but incremental findings that make a difference. We've done things and found things that have clearly changed people's lives or even saved them. That sounds pretentious, I know, but it's true, and there is just nothing more fulfilling or motivating than that. Of course, that type of thing doesn't happen every day; it's a process to get there, but you don't arrive unless you start."

\section{ACKNOWLEDGMENTS}

I express sincere gratitude to Robin Patel for her generous provision of an in-depth interview for this biographical feature. Certain content within this biographical feature would not have been possible without the tremendous assistance of Stefano Bertuzzi, Ph.D., Peter H. Gilligan, Ph.D., Alexander J. McAdam, M.D., Ph.D., Bobbi S. Pritt, M.D., 
Thomas F. Smith, Ph.D., Elitza S. Theel, Ph.D., Richard B. (Tom) Thomson, Jr., Ph.D., and

Shawn Vasoo, MBBS, MRCP.

\section{REFERENCES}

1. Munson E. 2018. Biographical Feature: Peter H. Gilligan, Ph.D., D(ABMM), F(AAM). J Clin Microbiol 57:e01872-18. https://doi.org/10.1128/JCM $.01872-18$

2. Munson E. 2017. Biographical Feature: Richard B. (Tom) Thomson, Jr., Ph.D., D(ABMM), F(AAM). J Clin Microbiol 56:e01888-17. https://doi.org/ 10.1128/JCM.01888-17.

3. Lessard C, Brochu É. 10 April 2012. Collège d'enseignement général et professionnel (CEGEP) in Quebec. In The Canadian Encyclopedia. Historica Canada, Toronto, Canada. https://www.thecanadianencyclopedia.ca/en/ article/college-denseignement-general-et-professionnel-cegep. Accessed 22 May 2020

4. Munson E. 2017. Biographical Feature: Thomas F. Smith, Ph.D. J Clin Microbiol 55:1237-1243. https://doi.org/10.1128/JCM.02384-16.

5. Patel R, Smith TF, Espy M, Wiesner RH, Krom RA, Portela D, Paya CV. 1994. Detection of cytomegalovirus DNA in sera of liver transplant recipients. J Clin Microbiol 32:1431-1434. https://doi.org/10.1128/JCM.32.6.1431 $-1434.1994$

6. Patel R, Paya CV. 1997. Infections in solid-organ transplant recipients. Clin Microbiol Rev 10:86-124. https://doi.org/10.1128/CMR.10.1.86.

7. Patel R, Badley AD, Larson-Keller J, Harmsen WS, Ilstrup DM, Wiesner RH, Steers JL, Krom RA, Portela D, Cockerill FR, Paya CV. 1996. Relevance and risk factors of enterococcal bacteremia following liver transplantation. Transplantation 61:1192-1197. https://doi.org/ 10.1097/00007890-199604270-00013.

8. Patel R, Uhl JR, Cockerill FR, III. 2001. Multiplex polymerase chain reaction detection of $\operatorname{van} A, \operatorname{van} B, \operatorname{van} C-1$, and $\operatorname{van} C-2 / 3$ genes in enterococci. Methods Mol Med 48:3-11. https://doi.org/10.1385/1-59259-077-2:3.

9. Patel R, Piper K, Cockerill FR, III, Steckelberg JM, Yousten AA. 2000. The biopesticide Paenibacillus popilliae has a vancomycin resistance gene cluster homologous to the enterococcal VanA vancomycin resistance gene cluster. Antimicrob Agents Chemother 44:705-709. https://doi.org/ 10.1128/aac.44.3.705-709.2000.

10. Patel R, Piper KE, Rouse MS, Steckelberg JM. 2000. Linezolid therapy of Staphylococcus aureus experimental osteomyelitis. Antimicrob Agents Chemother 44:3438-3440. https://doi.org/10.1128/aac.44.12.3438-3440 2000 .

11. Patel R, Piper KE, Rouse MS, Uhl JR, Cockerill FR, III, Steckelberg JM. 2000. Frequency of isolation of Staphylococcus lugdunensis among staphylococcal isolates causing endocarditis: a 20-year experience. J Clin Microbiol 38:4262-4263. https://doi.org/10.1128/JCM.38.11.4262-4263.2000.

12. Frank KL, Del Pozo JL, Patel R. 2008. From clinical microbiology to infection pathogenesis: how daring to be different works for Staphylo-

\section{SELECTED BIBLIOGRAPHY}

Patel R, Hughes RW, Jr. 1992. An unusual case of myxedema megacolon with features of ischemic and pseudomembranous colitis. Mayo Clin Proc 67: 369-372. https://doi.org/10.1016/S0025-6196(12)61554-7.

Sia IG, Patel R. 2000. New strategies for prevention and therapy of cytomegalovirus infection and disease in solid-organ transplant recipients. Clin $\mathrm{Mi}-$ crobiol Rev 13:83-121. https://doi.org/10.1128/CMR.13.1.83.

Wolk D, Mitchell S, Patel R. 2001. Principles of molecular microbiology testing methods. Infect Dis Clin North Am 15:1157-1204. https://doi.org/10 1016/S0891-5520(05)70190-2.

Paya CV, Wilson JA, Espy MJ, Sia IG, DeBernardi MJ, Smith TF, Patel R, Jenkins G, Harmsen WS, Vanness DJ, Wiesner RH. 2002. Preemptive use of oral ganciclovir to prevent cytomegalovirus infection in liver transplant patients: a randomized, placebo-controlled trial. J Infect Dis 185:854-860. https://doi .org/10.1086/339449.

Patel R. 2003. Clinical impact of vancomycin-resistant enterococci. J Antimicrob Chemother 51(Suppl 3):iii13-iii21.

Smith TF, Espy MJ, Mandrekar J, Jones MF, Cockerill FR, Patel R. 2007. Quantitative real-time polymerase chain reaction for evaluating DNAemia due to cytomegalovirus, Epstein-Barr virus, and BK virus in solid-organ transplant recipients. Clin Infect Dis 45:1056-1061. https://doi.org/10.1086/ 521909. coccus lugdunensis. Clin Microbiol Rev 21:111-133. https://doi.org/10 .1128/CMR.00036-07.

13. Trampuz A, Piper KE, Jacobson MJ, Hanssen AD, Unni KK, Osmon DR, Mandrekar JN, Cockerill FR, Steckelberg JM, Greenleaf JF, Patel R. 2007. Sonication of removed hip and knee prostheses for diagnosis of infection. N Engl J Med 357:654-663. https://doi.org/10.1056/ NEJMoa061588.

14. Saffert RT, Cunningham SA, Ihde SM, Jobe KE, Mandrekar J, Patel R. 2011 Comparison of Bruker Biotyper matrix-assisted laser desorption ionization-time of flight mass spectrometer to BD Phoenix automated microbiology system for identification of Gram-negative bacilli. J Clin Microbiol 49:887-892. https://doi.org/10.1128/JCM.01890-10.

15. Bharat A, Cunningham SA, Scott Budinger GR, Kreisel D, DeWet CJ, Gelman AE, Waites K, Crabb D, Xiao L, Bhorade S, Ambalavanan N, Dilling DF, Lowery EM, Astor T, Hachem R, Krupnick AS, DeCamp MM, Ison MG, Patel R. 2015. Disseminated Ureaplasma infection as a cause of fatal hyperammonemia in humans. Sci Transl Med 7:284re3. https://doi.org/ 10.1126/scitranslmed.aaa8419.

16. Chambers HF, Bartlett JG, Bonomo RA, Chiou C, Cosgrove SE, Cross HR, Daum RS, Downing M, Evans SR, Knisely J, Kreiswirth BN, Lautenbach E, Mickley BS, Patel R, Pettigrew MM, Rodvold KA, Spellberg B, Fowler VG., Jr. 2014. Antibacterial Resistance Leadership Group: open for business. Clin Infect Dis 58:1571-1576. https://doi.org/10.1093/cid/ciu132.

17. Chandrasekaran $S$, Abbott $A$, Campeau S, Zimmer BL, Weinstein $M$ Thrupp L, Hejna J, Walker L, Ammann T, Kirn T, Patel R, Humphries RM. 2018. Direct-from-blood-culture disk diffusion to determine antimicrobial susceptibility of Gram-negative bacteria: preliminary report from the Clinical and Laboratory Standards Institute methods development and standardization working group. J Clin Microbiol 56:e01678-17. https:// doi.org/10.1128/JCM.01678-17.

18. Tsalik EL, Petzold E, Kreiswirth BN, Bonomo RA, Banerjee R, Lautenbach E, Evans SR, Hanson KE, Klausner JD, Patel R, and the Diagnostics and Devices Committee of the Antibacterial Resistance Leadership Group. 2017. Advancing diagnostics to address antibacterial resistance: the Diagnostics and Devices Committee of the Antibacterial Resistance Leadership Group. Clin Infect Dis 64:S41-S47. https://doi.org/10.1093/ cid/ciw831.

19. Patel R, Babady E, Theel ES, Storch GA, Pinsky BA, St. George K, Smith TC, Bertuzzi S. 2020. Report from the American Society for Microbiology COVID-19 International Summit, 23 March 2020: value of diagnostic testing for SARS-CoV-2/COVID-19. mBio 11:e00722-20. https://doi.org/10 .1128/mBio.00722-20

Del Pozo JL, Patel R. 2009. Clinical practice. Infection associated with prosthetic joints. N Engl J Med 361:787-794. https://doi.org/10.1056/ NEJMcp0905029.

Vergidis P, Patel R. 2012. Novel approaches to the diagnosis, prevention, and treatment of medical device-associated infections. Infect Dis Clin North Am 26:173-186. https://doi.org/10.1016/j.idc.2011.09.012.

Vasoo S, Cunningham SA, Kohner PC, Simner PJ, Mandrekar JN, Lolans K, Hayden MK, Patel R. 2013. Comparison of a novel, rapid chromogenic biochemical assay, the Carba NP test, with the modified Hodge test for detection of carbapenemase-producing Gram-negative bacilli. J Clin Microbiol 51:3097-3101. https://doi.org/10.1128/JCM.00965-13.

Peel TN, Dylla BL, Hughes JG, Lynch DT, Greenwood-Quaintance KE, Cheng AC, Mandrekar JN, Patel R. 2016. Improved diagnosis of prosthetic joint infection by culturing periprosthetic tissue specimens in blood culture bottles. mBio 7:e01776-15. https://doi.org/10.1128/mBio.01776-15.

Uhl JR, Patel R. 2016. Fifteen-minute detection of Streptococcus pyogenes in throat swabs by use of a commercially available point-of-care PCR assay. J Clin Microbiol 54:815. https://doi.org/10.1128/JCM.03387-15.

Pritt BS, Mead PS, Johnson DKH, Neitzel DF, Respicio-Kingry LB, Davis JP, Schiffman E, Sloan LM, Schriefer ME, Replogle AJ, Paskewitz SM, Ray JA, Bjork J, Steward CR, Deedon A, Lee X, Kingry LC, Miller TK, Feist MA, Theel ES, Patel 
R, Irish CL, Petersen JM. 2016. Identification of a novel pathogenic Borrelia species causing Lyme borreliosis with unusually high spirochaetaemia: a descriptive study. Lancet Infect Dis 16:556-564. https://doi.org/10.1016/ S1473-3099(15)00464-8.

Pritt BS, Patel R, Kirn TJ, Thomson RB, Jr. 2016. Point-Counterpoint: A nucleic acid amplification test for Streptococcus pyogenes should replace antigen detection and culture for detection of bacterial pharyngitis. J Clin Microbiol 54:2413-2419. https://doi.org/10.1128/JCM.01472-16.

Fang FC, Patel R. 2017. 2017 Infectious Diseases Society of America infectious diarrhea guidelines: a view from the clinical laboratory. Clin Infect Dis 65:1974-1976. https://doi.org/10.1093/cid/cix730.

Miller JM, Binnicker MJ, Campbell S, Carroll KC, Chapin KC, Gilligan PH, Gonzalez MD, Jerris RC, Kehl SC, Patel R, Pritt BS, Richter SS, Robinson-
Dunn B, Schwartzman JD, Snyder JW, Telford S, III, Theel ES, Thomson RB, Jr, Weinstein MP, Yao JD. 2018. A guide to utilization of the microbiology laboratory for diagnosis of infectious diseases: 2018 update by the Infectious Diseases Society of America and the American Society for Microbiology. Clin Infect Dis 67:e1-e94. https://doi.org/10.1093/cid/ ciy381.

Wi YM, Patel R. 2018. Understanding biofilms and novel approaches to the diagnosis, prevention, and treatment of medical device-associated infections. Infect Dis Clin North Am 32:915-929. https://doi.org/10.1016/j.idc.2018 .06.009.

Carroll KC, Pfaller MA, Landry ML, McAdam AJ, Patel R, Richter SS, Warnock DW (ed). 2019. Manual of clinical microbiology, 12th ed. ASM Press, Washington, DC. 